\title{
ALGORITMA COCKE YOUNGER KASAMI UNTUK DETEKSI STRUKTUR KALIMAT DAN MEREKOMENDASIKANYA MENGGUNAKAN ALGORITMA DAMERAU LEVENSHTEIN DISTANCE
}

\author{
Budi Prabowo(1), Heru Cahya Rustamadji(2), Yuli Fauziah(3) \\ Jurusan Teknik Informatika Fakultas Teknik Industri UPN "Veteran" Yogyakarta \\ Jl. Babarsari 2 Tambakbayan Yogyakarta \\ e-mail : budiprabowo666@gmail.com ${ }^{(1)}$, herucr@upnyk.ac.id(2), yuli.if@gmail.com(3)
}

\begin{abstract}
The use of standard words and sentence structure is one of the requirements in writing research reports, unwittingly writing errors can occur either in the form of typographical errors or in the structure of sentences, some of which are habits when writing short messages, the development of everyday language and the arrangement of keyboards too close. Writing errors will usually be corrected immediately after finishing writing, but to correct them, time and accuracy are needed. CYK algorithm is a membership parsing algorithm for context-free grammar that can be used to examine sentence structure while the DLD algorithm is an algorithm that is able to calculate the distance difference between two strings so that it can be used for word and sentence recommendations. The purpose of this study is to apply the CYK algorithm to detect sentence structures and DLD algorithms to recommend words and sentence structure. Examination of sentences is done by grouping each word contained in the text based on its type, the words that have been grouped are then rearranged into sentences and examined by the CYK algorithm to find out whether the sentence is true or false, if the sentence is wrong then the sentence recommendations are used using the DLD algorithm with calculates the edit distance, besides repairs to the sentence the DLD algorithm also fixes the wrong words. The test results obtained the success rate of the CYK algorithm in detecting sentence structure by $96 \%$ and the DLD algorithm in recommending words by $96 \%$, while for recommending sentences by $88 \%$.
\end{abstract}

Keywords : Cocke Younger Kasami, Damerau Levenshtein Distance, Sentence Structure, Word, Bahasa Indonesia

\begin{abstract}
Abstrak
Penggunaan kata baku dan struktur kalimat merupakan salah satu syarat dalam penulisan laporan penelitian, tanpa disadari kesalahan penulisan dapat terjadi baik berupa kesalahan pengetikan maupun pada struktur kalimat, beberapa penyebabnya ialah kebiasaan saat menulis pesan pendek, berkembangnya bahasa yang digunakan sehari-hari dan susunan keyboard yang terlalu dekat. Kesalahan penulisan biasanya akan segera diperbaiki setelah selesai menulis, namun untuk memperbaikinya diperlukan waktu dan ketelitian. Algoritma CYK merupakan algoritma parsing keanggotaan untuk tatabahasa bebas konteks yang dapat digunakan untuk memeriksa struktur kalimat sedangkan algoritma DLD merupakan algoritma yang mampu menghitung jarak perbedaan dari dua buah string sehingga dapat dimanfaatkan untuk rekomendasi kata dan kalimat. Tujuan dari penelitian ini adalah menerapkan algoritma CYK untuk mendeteksi struktur kalimat dan algoritma DLD untuk merekomendasikan kata dan struktur kalimat. Pemeriksaan kalimat dilakukan dengan mengelompokan setiap kata yang terdapat pada teks berdasarkan jenisnya, kata yang telah dikelompokkan tersebut kemudian disusun kembali kedalam bentuk kalimat dan diperiksa dengan algoritma CYK untuk mengetahui apakah kalimat tersebut benar atau salah, jika kalimat salah maka diberikan rekomendasi kalimat menggunakan algoritma DLD dengan menghitung edit distance-nya, selain perbaikan pada kalimat algoritma DLD juga melakukan perbaikan pada kata yang salah. Hasil pengujian didapatkan tingkat keberhasilan algoritma CYK dalam mendeteksi struktur kalimat sebesar $96 \%$ dan algoritma DLD dalam merekomendasikan kata sebesar 96\%, sedangkan untuk merekomendasikan kalimat sebesar $88 \%$.
\end{abstract}

Kata Kunci : Cocke Younger Kasami, Damerau Levenshtein Distance, Struktur Kalimat, Kata, Bahasa Indonesia 


\section{PENDAHULUAN}

Penggunaan kata baku dan stuktur kalimat merupakan salah satu syarat dalam penulisan laporan penelitian, namun banyak diantara Mahasiswa Universitas Pembangunan Nasional "Veteran" Yogyakarta (UPN "Veteran" Yogyakarta) yang saat menulis tidak sengaja melakukan kesalahan dalam penggunaannya, seperti penulisan kata "yang" yang hanya ditulis dengan "yg" atau kata "pada" yang hanya ditulis dengan "pd" atau mungkin pada struktur kalimat seperti tertukarnya susunan subjek dengan predikat. Beberapa faktor penyebab kesalahan diantaranya kebiasaan mahasiswa saat mengetik pada pesan pendek seperti chat atau Short Message Service (SMS) menggunakan kata-kata yang disingkat, selain itu berkembangnya bahasa yang digunakan sehari-hari dikalangan generasi muda juga menjadi penyebab bergesernya bahasa Indonesia, sehingga saat menulis sebuah laporan penelitian yang seharusnya menggunakan kata baku dan struktur kalimat yang sesuai dengan kaidah tatabahasa Indonesia tergantikan oleh bahasa baru yang tidak terdapat dalam tatabahasa Indonesia namun dianggap lebih nyaman dan mudah untuk diungkapkan. Faktor lain disebabkan oleh kesalahan mekanis saat mengetik seperti letak huruf pada keyboard yang terlalu dekat sehingga menyulitkan pengetikan atau kesalahan jari yang tanpa sadar salah menekan tombol keyboard.

Kesalahan pada pengetikan biasanya akan segera diperbaiki setelah selesai menulis, jika teks yang ditulis sedikit tidak terlalu bermasalah tetapi jika teks sudah mencapai ribuan tentu akan menyulitkan sebab seseorang harus membaca teks berulang-ulang untuk mengetahui letak kesalahanya, dan tentu membutuhkan waktu dan juga ketelitian, selain itu Mahasiswa biasanya akan fokus kepada kesalahan besar terkait isi laporan penelitian sehingga proses deteksi kesalahaan pengetikan maupun struktur kalimat tidak diperhatikan, padahal hal yang kecil seperti kesalahan dalam pengetikan dapat berpengaruh terhadap informasi dan pengetahuan yang disampaikan.

Aplikasi editor teks seperti Microsoft Word memang sudah memerikan fasilitas speeling check untuk membantu penulis dalam mengoreksi teks tetapi tidak menjamin jalanya speeling check untuk bahasa Indonesia, sebab tidak ada acuan atau sumber yang jelas seperti Kamus Besar Bahasa Indonesia untuk memastikan bahwa kata tersebut terdaftar dalam bahasa Indonesia.

Berdasarkan permasalahan diatas untuk membantu mahasiswa dalam memeriksa kata dan struktur kalimat akan dibuat dalam sebuah program aplikasi menggunakan algoritma Cocke Younger Kasami (CYK) yang merupakan algoritma parsing dan keanggotaan untuk tatabahasa bebas konteks, algoritma CYK pada penelitian ini akan digunakan untuk menentukan struktur kalimat, sedangkan dalam memeriksa kata dan memberikan rekomendasi perbaikan kata dan struktur kalimat akan digunakan algoritma Damerau Levenshtein Distance(DLD) yang memiliki kemampuan dalam menghitung perubahan yang terjadi pada sebuah string.

\section{METODOLOGI PENELITIAN}

\subsection{Analisis Masalah}

Menulis merupakan kegiatan seseorang dalam mengutarakan ide dan pikirannya kedalam bentuk tulisan seperti paragraf, kalimat, atau kata. Saat menulis mahasiswa akan fokus untuk mengutarakan ide dan pemikirannya yang tanpa disadari kesalahan dalam penulisanpun terjadi. Penulisan yang salah harus segera diperbaiki agar sebuah tulisan mudah dibaca dan informasi tersampaikan kepada pembaca, dalam memperbaiki penulisan dibutuhkan ketelitian serta pengetahuan mengenai bentuk kata baku dan struktur kalimat yang sesuai dengan kaidah bahasa Indonesia. Bentuk kata baku dapat diketahui dari ada atau tidaknya kata dalam Kamus Besar Bahasa Indonesia, sedangkan struktur kalimat diketahui dari aturan pembentukan kalimat. Sebuah kalimat memiliki syarat pembentukan minimal terdapat unsur subjek dan predikat didalamnya. Pembentukan kalimat didasarkan pada aturan penggunaan subjek, predikat, objek, pelengkap, dan keterangan yang diatur dalam tatabahasa Indonesia.

\subsection{Pengumpulan Data}

Pengumpulan data dilakukan dengan mencari informasi tentang tatabahasa, Algoritma Damerau Levenshtein Distance dan CYK yang diperoleh dari jurnal, skripsi, dan website yang dapat 
dipertanggungjawabkan, selain itu dilakukan pencarian daftar kata dan kelompok kata pada Kamus Besar Bahasa Indonesia (KBBI).

\subsection{Rekomendasi Kata Menggunakan Algoritma DLD}

Proses ini dilakukan dengan memeriksa setiap kata dan memperbaiki kata yang tidak terdapat pada kamus data. Setiap kata yang diperiksa akan dibandingkan dengan kamus data. Perbaikan kata ditentukan dengan nilai edit distace terkecil yang dimiliki kata.

$$
d_{a, b}(i, j)=\left\{\begin{array}{l}
\max (i, j) \\
\min \left\{\begin{array}{l}
d_{a, b}(i-1, j)+1 \\
d_{a, b}(i, j-1)+1 \\
d_{a, b}(i-1, j-1)+1_{\left(a_{i} \neq b_{j}\right)} \\
d_{a, b}(i-2, j-2)+1
\end{array}\right. \\
\min \left\{\begin{array}{l}
d_{a, b}(i-1, j)+1 \\
d_{a, b}(i, j-1)+1 \\
d_{a, b}(i-1, j-1)+1_{\left(a_{i} \neq b_{j}\right)}
\end{array}\right.
\end{array}\right.
$$

Keterangan :

$\mathrm{d}=$ matrik

$\mathrm{a}=$ string sumber

$\mathrm{b}=$ string target

$\mathrm{i}=$ lebar matrik (banyaknya sting a)

$\mathrm{j}=$ panjang matrik (banyaknya string $\mathrm{b}$ )

$\min =$ minimal

max $=$ maksimal

Pembentukan Tabel Dua Dimensi

Pembentukan tabel dua dimensi pada algoritma $D L D$ dibentuk seperti pada Tabel 1.

Tabel 1. Pembentukan Tabel DLD

\begin{tabular}{|c|c|c|c|c|c|}
\hline $\mathbf{I} / \mathbf{J}$ & & $\mathbf{S}$ & $\mathbf{A}$ & $\mathbf{Y}$ & $\mathbf{A}$ \\
\hline & 0 & 1 & 2 & 3 & 4 \\
\hline $\mathbf{S}$ & 1 & & & & \\
\hline $\mathbf{Y}$ & 2 & & & & \\
\hline $\mathbf{A}$ & 3 & & & & \\
\hline
\end{tabular}

\section{Menghitung Edit Distance}

Setiap karakter yang terdapat pada tabel dihitung nilai edit ditance-nya, edit distance dihitung berdasarkan operasi yang dimiliki DLD yaitu insert, delete, substitusi, dan transposisi.

a. Inserting dan deleting dihitung dengan menambahkan nilai 1 (satu) pada sel sebelah kiri $[0,1]$ dan atas $[1,0]$ dari sel yang akan diisi $[1,1]$, nilai yang telah ditambahkan tersebut kemudian dimasukan kedalam sel yang menjadi pertemuan dari baris dan kolom karakter yang dibandingkan, pada pengisian awal sel yang dimaksud yaitu $[1,1]$.

b. Susbstitusi dihitung dengan menambahkan nilai 0 (nol) pada sel sebelah kiri atas $[0,0]$ dari sel yang akan diisi $[1,1]$ jika karakter yang dibandingkan berbeda namun jika karakternya sama maka nilai yang ditambahkan yaitu 1 (satu), nilai yang telah ditambahkan tersebut kemudian dimasukan kedalam sel yang menjadi pertemuan dari baris dan kolom karakter yang dibandingkan, pada pengisian awal sel yang dimaksud yaitu $[1,1]$.

c. Transposisi dihitung saat sel yang akan diisi berada pada baris dan kolom lebih dari satu, saat kondisi tersebut sel ditambahkan 1 (satu).

Tabel 2. Pengisian Tabel Dua Dimensi

\begin{tabular}{|c|c|c|c|c|c|}
\hline I/J & & $\mathbf{S}$ & $\mathbf{A}$ & $\mathbf{Y}$ & $\mathbf{A}$ \\
\hline & 0 & 1 & 2 & 3 & 4 \\
\hline $\mathbf{S}$ & 1 & 0 & 1 & 2 & 3 \\
\hline $\mathbf{Y}$ & 2 & 2 & 1 & 1 & 2 \\
\hline
\end{tabular}




\begin{tabular}{|l|l|l|l|l|l|}
\hline $\mathbf{A}$ & 3 & 3 & 2 & 1 & 1 \\
\hline
\end{tabular}

Jumlah perhitungan edit distance dari dua buah string diatas adalah 1 (satu), hasil perhitungan tersebut diperoleh dari sel terakhir pada tabel. Hasil tersebut kemudian dijadikan nilai parameter nilai rekomendasi untuk setiap kata yang dianggap salah.

\subsection{Perbaikan Struktur Kalimat Menggunakan Algoritma CYK dan Rekomendasi Struktur Kalimat menggunakan Algoritma $D L D$}

Proses pemeriksaan kalimat dilakukan dengan mengenali pola kalimat, dalam algoritma $C Y K$ pengenalan pola kalimat dapat dilakukan dengan menganalisis sintaksis dan aturan produksi.

\section{Sintaksis dan Aturan Produksi}

Algoritma CYK membutuhkan aturan produksi yang sudah dalam bentuk CNF, dan CNF memiliki aturan produksi yang sudah melalui penyederhanaan CFG sedangkan CFG memiliki aturan produksi berbentuk $\alpha \rightarrow \beta$ dimana $\beta$ tidak memiliki batasan, sehingga $\beta$ disini dapat diisi dengan tatabahasa Indonesia.

Sebelum membentuk tatabahasa Indonesia kedalam aturan produksi CFG, seluruh kata dikelompokan jenis katanya, masing-masing kelompok kata tersebut diberikan label secara acak dan menghasilkan kelompok kata.

Tabel 3. Pengelompokan Kata

\begin{tabular}{|l|c|l|}
\hline \multicolumn{1}{|c|}{ Kelompok kata } & Label & \multicolumn{1}{c|}{ Keterangan } \\
\hline Nomina & N & Kata benda \\
\hline Adjektiva & V & Kata sifat \\
\hline Verba & A & Kata kerja \\
\hline Adverbia & B & Pemberi keterangan pada kata \\
\hline Preposisi & R & Kata depan penghubung \\
\hline Demonstrativa & D & Kata tunjuk \\
\hline Konjungsi Subordinatif & H & Kata hubung kalimat koordinatif \\
\hline Negasi & I & Kata ingkar \\
\hline Modalitas & U & Kata kerja bantu \\
\hline Adjektiva/Verba Prefiks & A3 & $\begin{array}{l}\text { Kata kerja yang tidak memerlukan objek } \\
\text { (menyatakan paling) }\end{array}$ \\
\hline Prefiks-Verba Transitif & A4 & Kata kerja memerlukan objek \\
\hline Prefiks-Verba Intransitif & A5 & Kata kerja yang tidak memerlukan objek \\
\hline Sufiks-Nomina & T & Kata benda pengganti \\
\hline Prefiks-Nomina Pemakai & N1 & Kata benda yang menyatakan kepemilikan \\
\hline Negasi Nomina & I1 & Kata ingkar untuk predikat berkategori nomina \\
\hline Konjungsi Penjelas & H1 & Konjungsi yang menperjelas subjek \\
\hline Konjungsi Penggambaran & A2 & $\begin{array}{l}\text { Kata kerja yang memiliki fungsi menggambarkan } \\
\text { subjek }\end{array}$ \\
\hline Konjungsi Koordinatif & H2 & Kata hubung \\
\hline Verba Deskriptif & A1 & Kata kerja untuk mendeskripsikan subjek \\
\hline
\end{tabular}

Kelompok kata yang terbentuk diatas selanjutnya digunakan sebagai terminal simbol untuk aturan produksi. Kelompok kata tersebut adalah terminal simbol yang mewakili seluruh kata yang telah dikelompokan. Daftar kata yang telah dikelompokan tersebut disimpan dalam sebuah file system yang dipisah sesuai dengan kelompok katanya.

Kalimat dibentuk dengan minimal terdapat subjek dan predikat, untuk objek dan pelengkap berada dibelakang predikat, terkecuali objek pada kalimat intransitif dapat ditempatkan didepan predikat, sedangkan keterangan karena dapat ditempatkan dimana saja.

Sebuah aturan produksi harus memiliki keterkaitan antara unit satu dengan yang lain, guna fleksibilitas dalam penggunaan variabel simbolnya, sebuah aturan produksi dibentuk dengan susunan sebagai seperti Gambar 1. 


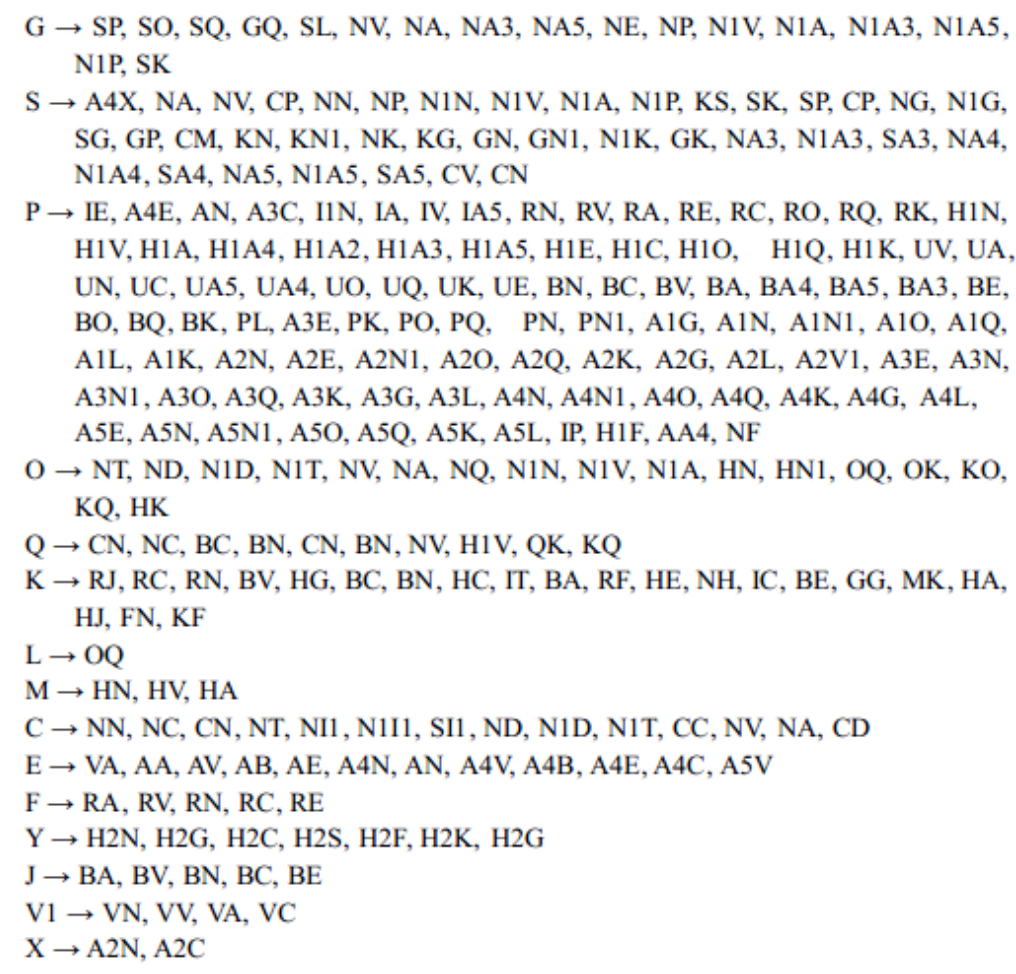

Gambar 1. Aturan produksi

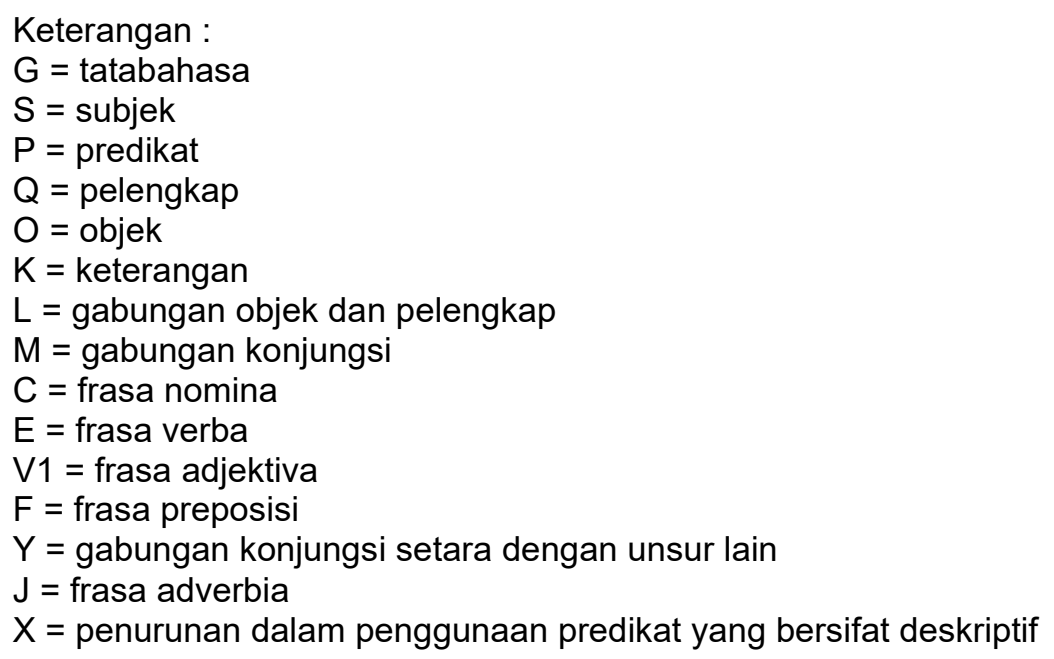

Variabel unit "G" pada aturan produksi diatas memuat 19 (sembilan belas) pola kalimat meliputi SP, SPO, SPQ, SPOQ, KSP, KSPO, KSPQ, KSPOQ, SKP, SKPO, SKPQ, SKPOQ, SPK, SPKO, SPKQ, SPKOQ, SPOK, SPOKQ, SPOQK dengan masing-masing unsur kalimat seperti subjek, predikat, objek, pelengkap dan keterngan memiliki penurunan berupa kata, frasa maupun klausa pada kalimat luas koordinatif.

\subsection{Pemeriksaan pola kalimat menggunakan algoritma CYK}

Tahap ini melakukan pemeriksaan pada setiap kalimat untuk mengetahui apakah kalimat tersebut sesuai dengan aturan produksi atau tidak, sebagai contoh terdapat sebuah kalimat "Belajar kakak di kamar". Setiap kata yang terdapat pada kalimat memiliki unsur pembentukan, unsur-unsur tersebut adalah bagian dari terminal simbol yang terdapat pada aturan produksi. 


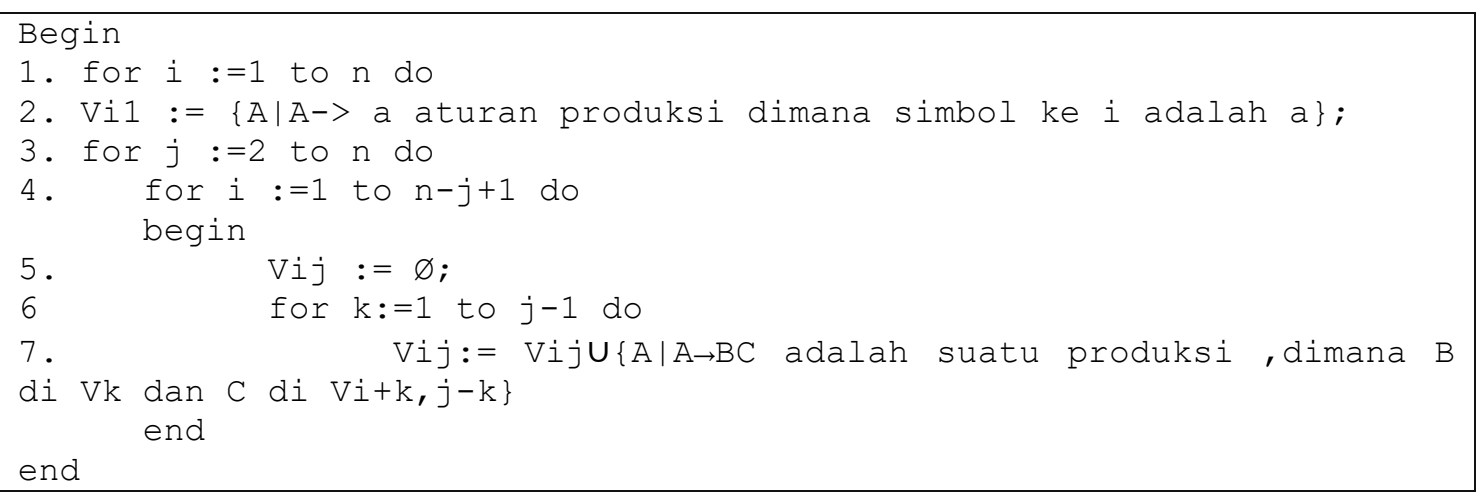

Psudecode 1. Algoritma CYK

Psudecode diatas membentuk matrik berukuran panjang sebanyak simbol yang akan diuji. Setiap sel diisi oleh $\mathrm{x}$. Pembentukan tersebut didasarkan pada for $\mathrm{i}:=1$ to $\mathrm{n}$ do , dengan pengisian sel berupa $x$ ditunjukan pada baris kedua. Baris ketiga yaitu for $\mathrm{j}:=2$ to $\mathrm{n}$ do melakukan pengisian dari baris kedua hingga $n$, pengisian dari for $i:=1$ to $n-j+1$ do, jika $j=2$ maka $n-2+1$, jika $j=3$ maka $n-3+1$. Baris ke enam yaitu for $k:=1$ to $j-1$ do adalah pengisian yang bergerak dari 1 hingga $j-1$ yang diisi dengan baris ke tujuh berupa $\mathrm{Vij}_{\mathrm{ij}}\{\mathrm{A} \mid \mathrm{A} \rightarrow \mathrm{BC}$, vij atau disebut dengan sel diisi dengan non terminal simbol yang memproduksi BC dimana $\mathrm{B}$ adalah $\mathrm{Vk}$ dan $\mathrm{C}$ di $\mathrm{Vi}+\mathrm{k}, \mathrm{j}-\mathrm{k}$.

Pemeriksaan kalimat menggunakan algoritma CYK yang dilakukan untuk menemukan susunan kalimat "Belajar kakak di kamar" diperoleh dengan cara membentuk tabel matrik dua dimensi dengan jumlah kolom dan baris sebanyak jumlah kata yang akan diperiksa. Setiap kata yang terdapat pada kalimat ditempatkan pada setiap kolom tabel, seperti yang ditunjukkan pada tabel berikut.

Tabel 4. Pemeriksaan pola kalimat dengan algoritma CYK

\begin{tabular}{||c|c|c|c|}
\hline Belajar & kakak & di & kamar \\
\hline & & & \\
\hline & & & \multicolumn{2}{|c}{} \\
\hline & & \multicolumn{2}{|c}{} \\
\hline
\end{tabular}

Setiap sel yang kosong yang terdapat pada baris pertama diisi dengan nonterminal simbol yang menurunkan terminal simbol "belajar", "kakak", "di", "kamar", sehingga akan terbentuk tabel seperti berikut :

Tabel 5. Pengisian tabel baris pertama

\begin{tabular}{|c|c|c|c|c|}
\hline & Belajar & Kakak & di & Kamar \\
\hline 1 & V V & $\begin{array}{l}\mathrm{N} \\
\end{array}$ & $\mathrm{R}$ & $\begin{array}{l}\mathrm{N} \\
\end{array}$ \\
\hline 2 & & & & \\
\hline 3 & & & & \\
\hline 4 & & & & \\
\hline
\end{tabular}

Pengisian pada baris kedua diperoleh dengan mengambil nonterminal simbol yang berada pada posisi atas dan kanan atas dari sel yang akan diisi, agar mempermudah proses pengisian pengisian dibuat tabel bantuan untuk menyimpan data sementara seperti berikut :

Tabel 6. Tabel bantuan pengisian baris kedua

\begin{tabular}{|c|c|c|c|}
\hline$\downarrow$ & $\checkmark$ & Gabungan & Ruas kiri \\
\hline $\mathrm{V}$ & $\mathrm{N}$ & $\mathrm{VN}$ & $\mathrm{E}, \mathrm{P}$ \\
\hline
\end{tabular}




\begin{tabular}{|c|c|c|c|}
\hline $\mathrm{N}$ & $\mathrm{R}$ & $\mathrm{NR}$ & $\varnothing$ \\
\hline $\mathrm{R}$ & $\mathrm{N}$ & $\mathrm{RN}$ & $\mathrm{F}, \mathrm{K}, \mathrm{P}$ \\
\hline
\end{tabular}

Hasil yang diperoleh pada tabel 6 terdapat pada kolom ruas kiri, simbol " $\varnothing$ " merupakan simbol yang menyatakan bahwa tidak ada nonterminal simbol yang menurunkan "NR" atau dapat diartikan produksi kosong. Hasil yang terdapat pada ruas kiri tabel 6 kemudian menjadi data yang diisikan pada tabel CYK, sehingga diperoleh hasil sementara seperti pada Tabel 7.

Tabel 7. Pengisian baris kedua

\begin{tabular}{|c|c|c|c|c|}
\hline & Belajar & Kakak & di & Kamar \\
\hline 1 & $\mathrm{~V}$ & $\mathrm{~N}$ & $\mathrm{R}$ & $\mathrm{N}$ \\
\hline 2 & $\downarrow \mathrm{E}, \mathrm{P}$ & $\varnothing$ & $\mathrm{F}, \mathrm{K}, \mathrm{P}$ & \\
\hline 3 & & & \multicolumn{3}{|c}{} \\
\hline 4 & & & \multicolumn{3}{|c}{} \\
\hline
\end{tabular}

Pengisian pada baris ketiga sama seperti sebelumnya, namun nonterminal simbol yang digabungkan harus terurut, dimulai dari penggabungan baris pertama kolom "Belajar" dengan baris kedua kolom "Kakak", kemudian baris kedua kolom "Belajar" dengan baris pertama kolom "di", untuk pengisian pada sel dikolom berikutnya juga sama hanya perlu menyesuaikan posisi kolomnya.

Tabel 8. Tabel bantuan pengisian baris ketiga pada tabel CYK

\begin{tabular}{|c|c|c|c|}
\hline$\downarrow$ & \multicolumn{1}{|c|}{ Gabungan } & Ruas kiri \\
\hline $\mathrm{V}$ & $\varnothing$ & $\mathrm{V} \varnothing$ & $\varnothing$ \\
\hline $\mathrm{E}, \mathrm{P}$ & $\mathrm{R}$ & $\mathrm{ER}, \mathrm{PR}$ & $\varnothing$ \\
\hline $\mathrm{N}$ & $\mathrm{F}, \mathrm{K}, \mathrm{P}$ & $\mathrm{NF}, \mathrm{NK}, \mathrm{NP}$ & $\mathrm{P}, \mathrm{S}, \mathrm{G}$ \\
\hline$\varnothing$ & $\mathrm{N}$ & $\varnothing \mathrm{N}$ & $\varnothing$ \\
\hline
\end{tabular}

Tabel diatas pada kolom ruas kiri terdapat warna biru dan hijau, masing-masing warna tersebut mewakili sel yang terdapat pada tabel CYK, pada tabel diatas terdapat 2 (dua) baris pada ruas kiri dengan warna biru memiliki hasil yang sama untuk penempatan yang sama, dalam penempatanya pada tabel CYK cukup diisikan sekali saja, sedangkan pada ruas kiri yang ditandai dengan warna hijau terdapat nonterminal simbol "P,S,G" dan " $\varnothing$ " maka untuk produksi kosong atau " $\varnothing$ " tidak perlu dituliskan.

Tabel 9. Pengisian baris ketiga kolom pertama

\begin{tabular}{|c|c|c|c|c|}
\hline & Belajar & Kakak & di & Kamar \\
\hline 1 & $\mathrm{~V}$ & $\mathrm{~N}$ & $\mathrm{R}$ & $\mathrm{N}$ \\
\hline 2 & $\mathrm{E}, \mathrm{P}$ & $\varnothing$ & $\mathrm{F}, \mathrm{K}, \mathrm{P}$ & \\
\cline { 1 - 2 } 3 & $\varnothing$ & $\mathrm{P}, \mathrm{S}, \mathrm{G}$ & \multicolumn{3}{|c}{} \\
\hline 4 & \multicolumn{3}{|l|}{} \\
\hline
\end{tabular}

Pengisian baris terakhir sama seperti pada pengisian baris ketiga, isi yang terdapat pada baris terakhir merupakan penentu apakah kalimat dapat dinyatakan benar atau salah.

Tabel 10. Tabel bantuan pengisian baris keempat pada tabel CYK

\begin{tabular}{|c|c|c|c|}
\hline$\downarrow$ & & Gabungan & Ruas kiri \\
\hline $\mathrm{V}$ & $\mathrm{P}, \mathrm{S}, \mathrm{G}$ & $\mathrm{VP}, \mathrm{VS}, \mathrm{VG}$ & $\varnothing$ \\
\hline $\mathrm{E}, \mathrm{P}$ & $\mathrm{F}, \mathrm{K}, \mathrm{P}$ & $\mathrm{EF}, \mathrm{EK}, \mathrm{EP}, \mathrm{PF}, \mathrm{PK}, \mathrm{PP}$ & $\mathrm{P}$ \\
\hline$\varnothing$ & $\mathrm{N}$ & $\varnothing \mathrm{N}$ & $\varnothing$ \\
\hline
\end{tabular}

Warna hijau pada tabel diatas memiliki 2 (dua) produksi kosong dengan dan 1 (satu) nonterminal simbol, hasil pengisian dapat dilihat pada Tabel 11. 
Tabel 11. Pengisian baris keempat

\begin{tabular}{|c|c|c|c|c|}
\hline & Belajar & Kakak & di & Kamar \\
\hline 1 & $\mathrm{~V}$ & $\mathrm{~N}$ & $\mathrm{R}$ & $N$ \\
\hline 2 & $E, P$ & $\varnothing$ & $-F, K, P$ & \\
\hline 3 & $\varnothing$ & P,S,G & & \\
\hline 4 & $\checkmark P$ & & & \\
\hline
\end{tabular}

Hasil yang ditunjukan pada tabel diatas menandakan kalimat tidak dapat dikenali, sebab hasil akhirnya tidak mencapat start symbol "G".

\subsection{Perbaikan pola kalimat menggunakan algoritma $D L D$}

Bagian ini menjelaskan cara untuk memperbaiki pola kalimat yang keliru. Hasil akhir dari tabel 11 pola kalimat tidak dikenali karena tertukarnya kata "belajar" dengan kata "kakak". Perbaikan pola kalimat dilakukan dengan langkah awal membuat data kamus untuk pembanding susunan kalimatnya.

Perbaikan pola kalimat sama seperti perbaikan kata dengan algoritma $D L D$. Berikut ini pola kalimat yang diperbaiki menggunakan algoritma $D L D$ pada Tabel 12.

Tabel 12. Perbandingan pola kalimat

\begin{tabular}{|c|c|c|c|c|c|c|}
\hline & & & Belajar & Kakak & di & Kamar \\
\hline & & & $\mathbf{c}$ & $\mathbf{a}$ & $\mathbf{f}$ & $\mathbf{a}$ \\
\hline & & $\mathbf{0}$ & $\mathbf{1}$ & $\mathbf{2}$ & $\mathbf{3}$ & $\mathbf{4}$ \\
\hline Kakak & $\mathbf{a}$ & $\mathbf{1}$ & 1 & 1 & 2 & 3 \\
\hline Belajar & $\mathbf{c}$ & $\mathbf{2}$ & 1 & 1 & 2 & 3 \\
\hline di & $\mathbf{f}$ & $\mathbf{3}$ & 2 & 2 & 1 & 3 \\
\hline Kamar & $\mathbf{a}$ & $\mathbf{4}$ & 3 & 2 & 2 & $\mathbf{1}$ \\
\hline
\end{tabular}

Proses perbandingan pola kalimat dilakukan dengan seluruh data kamus, data kamus yang memiliki nilai terendah akan menjadi rekomendasi untuk perbaikan kalimat.

\section{HASIL DAN PEMBAHASAN}

Penerapan algoritma CYK dalam memeriksa kalimat sederhana maupun memeriksa kalimat luas menunjukan hasil yang baik, dalam memeriksa kalimat sederhana hasil pengujian menunjukan seluruh kalimat dapat diperiksa, namun pada kalimat luas terdapat dua kalimat yang tidak berhasil diperiksa atau hasil pengujian menunjukan bahwa kalimat tersebut salah, kesalahan disebabkan karena lengkapnya aturan produksi yang dibuat, Penelitian ini menggunakan aturan produksi dari beberapa sample kalimat sehingga tidak dapat memeriksa seluruh bentuk atau pola dari kalimat.

Algoritma $D L D$ sebagai algoritma yang digunakan untuk memberi rekomendasi perbaikan baik kata maupun kalimat pada pengujian menunjukan hasil yang baik dalam memeriksa kata, kegagalan dalam pemeriksaan disebabkan oleh banyaknya perbedaan pada kata yang dimasukan dan kata yang seharusnya menjadi rekomendasi, banyaknya perbedaan pada susunan kata dapat diartikan bahwa kata sama sekali tidak mirip dengan kata manapun, kondisi terebut pada sistem telah ditanggulangi dengan menampilkan pemberitahuan kepada pengguna bahwa kata yang dimasukan tidak terdapat dalam kamus. Penerapan lain algoritma DLD yaitu merekomendasikan kalimat sederhana, namun hasil rekomendasi untuk pemeriksaan tidak terlalu baik, dari sepuluh kalimat sederhana yang dimasukan hanya 6 (enam) kalimat yang berhasil memberikan rekomendasi sesuai dengan kalimat yang diharapkan sedangkan pada pemeriksaan kalimat luas hanya 5 (lima) kalimat. Hal ini disebabkan karena algoritma DLD mencari minimum edit distance yang dihasilkan menunjuk bentuk kalimat yang mendekati kalimat 
masukan, sedangkan kalimat yang diharapkan belum tentu kalimat yang mendekati dengan kalimat salah yang dimasukan. Kondisi ini mirip dengan rekomendasi kata saat menemukan susunakn kata yang bentuk katanya berbeda jauh.

\section{KESIMPULAN}

Berdasarkan hasil pengujian terhadap algoritma CYK dan algoritma Damerau Levenshtein distance disimpulkan bahwa algoritma CYK dapat mengenali kalimat dengan baik sesuai dengan aturan produksi yang dibuat, semakin banyak aturan produksi yang dibuat maka semakin banyak pola yang dapat dikenali. Algoritma $D L D$ juga baik dalam merekomendasikan kata, namun untuk rekomendasi kalimat masih kurang baik akibat nilai edit distance yang terendah.

\section{DAFTAR PUSTAKA}

Erlin, A. 2017. Pengertian Kata, Hakikat Kata dan Pengklasifikaian Kata. https://argadiaerlin97.wordpress.com/2017/06/22/pengertian-kata-hakikat-kata-dan\%09penglasifikasian-kata, diakses 17 Maret 2018.

Hayati, V.N. 2014. Aplikasi Segmentasi Teks Bahasa Indonesia Menggunakan Metode Context Free Grammar Untuk Pencocokan Kalimat Skripsi. Skripsi Universitas Islam Negeri Maulana Malik Ibrahim Malang.

Maghfira, T., Cholissodin, I. \& Widodo, A. 2017. Deteksi Kesalahan Ejaan dan Penentuan Rekomendasi Koreksi Kata yang Tepat Pada Dokumen Jurnal JTIIK Menggunakan Dictionary Lookup dan Damerau-Levenshtein Distance. Jurnal Pengembangan Teknologi Informasi Dan Ilmu Komputer, 1(6), 498-506.

Malik, A.K. 2011. Unsur-Unsur Pembentuk Kalimat. https://akmalik.wordpress.com/materi\%09kuliah/bahasa-indonesia/modul-2-unsur-unsur-pembentuk-kalimat/. Diakses 17 Maret 2018

Pahdi, A. 2016. Koreksi Ejaan Istilah Komputer Berbasis Kombinasi Algoritma DamerauLevenshtein dan Algoritma Soundex. Journal Speed-Sentra Penelitian Engineering Dan Edukasi-,8(2),1-8.

Pyriana, D.R., Suprapto., \& Suharsono. 2012. Program Aplikasi Editor Kata Bahasa Indonesia Menggunakan Metode Approximate String Matching Dengan Algoritma Levenshtein Distance Berbasis Java . Program Studi Teknik Informatika Un. Program Studi Teknik Informatika Universitas Brawijaya, 1-10.

Rachmawati, I. 2016. Pengertian Klausa dan Jenis - Jenis Klausa. https://portalilmu.com/pengertian-dan-jenis-jenis-klausa/. Diakses 17 Maret 2018

Setyawan, C.A. 2016. Program Dinamis dan Pencocokan String untuk Penyelesaian Soal Pemrograman Kompetitif. Makalah IF2211 Strategi Algoritma, Semester II Tahun 2015/2016. ITB, Bandung, Indonesia

Susanti, S. 2016. Analisis Perbandingan Algoritma Lcp(Left-Corner-Parsing) Dan Algoritma Cyk (Cocke-Younger-Kasami) Untuk Memeriksa Pola Kalimat Baku Bahasa Indonesia. Universitas Komputer Indonesia.

Wahyudipraja, M.F. 2015. Implementasi Algoritma Cocke -Younger-Kasami (CYK) Dan Levenshtein Untuk Merekomendasikan Perbaikan Struktur Kalimat Dan Kesalahan Pengetikkan Bahasa Indonesia. Skripsi Universitas Komputer Indonesia.

Warsito, A. 2017. 6 Jenis-jenis Klausa Verbal dan Contohnya dalam Kalimat. https//dosenbahasa.com/jenis-jenis-klausa-verbal. diakses 17 Maret 2018 